\title{
Assessment of Socio-economic Profiles for the Livelihood Generation of Bandha Weavers of Cuttack District of Odisha
}

\author{
Shubhasri Sahoo* \\ Department of Textile and Apparel Designing, College of Community Science, \\ OUAT, Bhubaneswar, Odisha, India \\ *Corresponding author
}

\begin{abstract}
A B S T R A C T
Keywords

Handloom, Bandha, Bandha weavers, Socio-economics, Cuttack, Odisha

Article Info

Accepted:

18 November 2020

Available Online:

10 December 2020

The documentation of traditional Bandha weavers was done in Cuttack district of Odisha where three selected villages were surveyed through purposive and simple random sampling techniques having 153 respondents. Majority $(80.39 \%)$ of respondents were above 35 years age, $83 \%$ had nuclear family system, $50.33 \%$ had education up to primary level, $54.91 \%$ belonged to OBC, $42.48 \%$ minority OBC (Buddhist), $79.74 \%$ had ration card holders, $98.69 \%$ male members engaged in Bandha work, $42.48 \%$ had major occupation of Bandha making and weaving, 30.72\% only Bandha making, $59.48 \%$ had rich experience in Bandha work more than 20 years and their major source of learning was from their ancestors, $77.78 \%$ worked 4-8 hours/day, mostly in their inherited house, $48.37 \%$ members of weavers cooperative society, $24.18 \%$ members of SHGs and weavers cooperative society and mostly not using advanced tools and equipments. Majority $(50.33 \%)$ of respondents were generating meagre income of within Rs.5000/- per month by engaged in various ways on Bandha work and have not much of subsidiary income as $64.05 \%$ were landless, indicating majority of the respondents were very poor socioeconomic status. So some recommendations were forwarded to Govt. to sustain their livelihood as well as the Bandhaart of Odisha.
\end{abstract}

\section{Introduction}

India has a rich tradition of handloom weaving since time immemorial with the earliest evidences going back to the Indus Valley civilization (Fourth All India Handloom Census, Govt. of India, 2019). It is an old practice of indigenous community and its knowledge has been passed from one generation to another (Pangging et al., 2020). Millions of rural peoples are economically dependent on their inherited craftsmanship
(Roy and Basu, 2020). The strength of handloom lies in innovative designs which cannot be replicated by the Power loom sector (Lakshmy Devi, 2014). This sector has an advantage of being less capital intensive, minimal use of power, eco-friendly, flexibility of small production, openness to innovations and adaptability to market requirements (Sudhakar and Padmavathi, 2019). This sector is an important second position employer in the country after agriculture by contributing to nearly $30 \%$ of total exports (Vijaya 
Lakshmi Vet al., 2019).It plays a key role in the Indian Economy by way of significant contribution to GDP, manufacturing output, employment generation and export earnings (Outcome budget, Govt. of India, 2015). Indian textile industry is the $2^{\text {nd }}$ largest manufacturer and exporter in the world. It contributes $7 \%$ of industry output in value terms, $2 \%$ of India's GDP, $15 \%$ of country's export earnings, more than $75 \%$ of total textiles production in the country. $95 \%$ of the world's hand woven fabric comes from India. India is a share of $5 \%$ of the global trade in textiles and apparel (Annual report, Govt. of India, 2018).

This handloom industry is a part of country's culture and one of the oldest cottage industries throughout the country (Banerjee et al., 2019). It is one of the largest sources of employment generation in the country with over 45 million people employed directly in rural areas (Outcome budget, Govt. of India, 2015;Annual report, Govt. of India, 2018).This sector provides employment to 43.31 lakhs persons of which $10 \%$ are from scheduled castes, $18 \%$ belong to scheduled tribes, $45 \%$ belong to Other Backward Classes (Prayas, Govt. of India, 2015). It provides employment to nearly 65 lakh of people and people are depending upon the ancillary occupations connected with this Industry (Sudhakar and Padmavathi, 2019). It plays an important role in the socio-economic development of any country. Particularly in rural belts, it is the source of livelihood to several millions of artisans and their families all over the world (Tripathy, 2009). In Odisha, handloom constitutes an integral part of the rural as well as semi- rural livelihood (Mishra, 2018). Weaving is a family enterprise where children to old man in the family involved in various weaving related activities (Vijaya Lakshmi V et al., 2019). This sector is largely household-based, carried out with labour contributed by the entire family. The total number of households in India engaged in handloom activities (weaving and allied activities) is 31.45 lakhs. 22.5 lakhs $(88.7 \%)$ weaver households are located in rural areas while 2.8 lakhs $(11.3 \%)$ are in urban areas (Fourth All India Handloom Census, Govt. of India, 2019).

The word Ikat is originally derived from the Malayan word "Magnikat" which means winding around, tying or binding. Ikat technique is one of the oldest and ancient methods of fabric ornamentation. It is defined as the evolvement of designs by the handresist-dyeing process in yarn/fabrics. The yarn resist process is widely adopted method of ornamentation with intricacy, fineness and craftsmanship throughout the design development rather than that of fabric Ikat ornamentation. Such Ikat fabrics produced in leading handloom clusters of India play a vital role in the export market and attract foreign consumers to its market sphere in comparison to other countries in rest of the world. Ikat is present over the world in different names (Behera et al., 2019). In Odisha, it is locally called Bandha and is in existence from 12th Century AD at Nuapatna of Cuttack district as per MadalaPanji of Jagannath Temple of Odisha (Behera et al., 2019; Panda and Parida, 2019; Amaravathi and Bhavana, 2019). Odisha holds $4^{\text {th }}$ position in India in registered GIs (14). Out of 14goods, 9 textile items are registered by the Department of Textiles, Government of Odisha and Ikat fabrics come under registered goods (Raju and Chaudhary, 2013).

Odisha, the land famous for its rich heritage and artistic culture has high tradition of its handloom products specially known as Ikat fabrics (Outcome budget, Govt. of Odisha, 2017). It has the tradition of Ikat across almost the entire state, mainly in Bolangir, Subanapur, Bargarh, Boudh and Cuttack districts. The Ikat technique in this area, as per history belongs to King Ramchandra of Puri in 1719 A.D. and also Jaydev, the great 
poet (Report of Textile Committee, Govt. of India, 2008). The areas of Ikat production of Cuttack district are in four blocks namely Baramba, Tigiria, Banki and Athagarh (Rath and Panda, 2017). The Nuapatna handloom cluster of the Cuttack district finds a prominent place on the handloom map of India, for its multi-coloured Ikat products. The main traditional Ikat products of the Nuapatna cluster are Khandua, Taraballi and Nabakothari to which contemporary designs in weft Ikat in mulberry silk, cotton and tasar have been added (Prayas, Govt. of India, 2015). The distinctive feature of Ikat is the Ikat design derived from nature and religious themes, is being survived today at the skilled hands of the interior rural handloom weavers and this Ikat in different parts of Cuttack district is called in the name of Khandua (Report of Textile Committee, Govt. of India, 2008). Khandua sari and fabrics are the unique traditional products of Cuttack district of Odisha, reflecting the essence of traditional way of life with expression of their unparalleled craftsmanship (Raju and Chaudhary, 2013; Rath and Panda, 2017). Gitagobinda Khanduapata on which Gitagobinda lyrics are written on Bandha technique is a special lord's fabric, Puri (Patra, 2015). Khandua silk saris are very famous in all over India for its excellent workmanship, design and colour combination (Panda and Parida, 2019).

In Odisha, Bandha is done by tying and dyeing the yarn either in warp or weft or both which is much more intricate than simple handloom weaving (Das, 1994). Historically it is the Bhulia and Kostha weavers of western districts (Sambalpur and other districts of western part) and Gaudia and Asanipataras and Sarakas (Budhists) of coastal districts (Cuttack and other districts of eastern part) are highly skilled Bandha weavers in Odisha (Das, 1994; Das Ghosh and Jena, 2018). With a population of 7000,
Nuapatna has 5000 registered weavers (Rath and Panda, 2017; Panda and Parida, 2019).

Handloom workers are the poorest, least socially respected, economically deprived, living in debts and almost living like an island in the Indian society still in the 21 st century (Banerjee et al., 2019). Irrespective of the Govt. policies, projects and aspirations, handloom sector impacting the livelihoods of the weavers and threat to the socio-economic life of the traditional weaver communities (Mohapatra, 2014). Now weavers are migrating to another profession and younger generations are not interested in taking handloom as a profession (Amaravathi and Bhavana, 2019). Market fluctuations, involvement of middle man, lack of awareness about govt. schemes etc. restrict the economic growth as well as the sustainability of the livelihood of the handloom weavers (Anand, 2017).

Weavers are facing a number of challenges like financial constraint, inability to purchase up-to-date machineries, poor working condition, meagre remuneration and the absence of government support(Das, 2015). They are facing severe livelihood crisis because of increased unfair competition from the power loom as handloom products are being replicated on power looms at much lower cost and mill sectors are responsible for the crisis (Lakshmy Devi, 2014; Maulik and Agarwal, 2014; Raju and Rao, 2014). Majority $(66.3 \%)$ of the weaver households earn less than Rs.5, 000/- per month and earning between Rs.5000 to Rs.10, 000 per month has gone up to $26.3 \%$ (Fourth All India Handloom Census, Govt. of India, 2019). The average daily income of the weavers have not exceeded beyond Rs.140 per day and the average monthly income not exceeding Rs.3500 per month (Rath and Panda, 2017). The average working day of a weaver is 280 to 300 days per annum and an average earns 
Rs.2000 to Rs.3000 per month (Panda and Parida, 2019). Weavers were dependent on weaving for their livelihood and majority $(76.3 \%)$ of the weavers were earning wages below Rs.50, 000 per annum (Raju G N and Rao, 2014).

In the above context, the present research work is carried out at College of Community Science, Department of Textile and Apparel Designing under Orissa University of Agriculture and Technology, Bhubaneswar, Odisha. The main objective of the study is to document the socio-economic profiles for the livelihood generation of traditional Bandha weavers of Cuttack district of Odisha.

\section{Materials and Methods}

\section{Study sites}

The present study was carried out in three villages namely Nuapatana, Maniabandha and Ragadipatana of blocks Tigiria, Baramba and Banki-II/Bankidamapara respectively of Cuttack district, coming under east coastal plain zone of Odisha, India (Fig. 1). The geographical area of the Cuttack district is $3,932 \mathrm{sq} . \mathrm{km}$. The district is situated in $20^{\circ} 5^{\prime}$ North latitude and $85^{\circ} 83^{\prime}$ East longitude. The Bandha weavers are the traditional handloom weavers of the selected villages.

\section{Experimental design}

Ex-Post facto Survey research design was considered to gather data. The district, subdivisions, blocks, and gram panchayats were selected purposively. Simple random sampling techniques were followed to select villages and respondents for study, having sample size 153 .

\section{Techniques employed}

Personal interview and focused group discussion techniques were used for collection of information from respondents of selected villages by close ended questions. The data collected were tabulated and statistically analysed with the help of frequency and percentage.

\section{Results and Discussion}

\section{Age}

Age is a crucial variable for the development and empowerment of the individuals. It is significant in terms of experience, maturity of judgement and decision making. The data collected on age distribution of the respondents was enlisted in table 1.

From the table it is revealed that majority $(44.44 \%)$ of the respondents were within 35 to 50 years followed by upper age $35.95 \%$ and only $19.61 \%$ belonged to young age.

The findings are that majority of the respondents were 35 years and above involving in Bandha weaving whereas younger aged people were not much involved in weaving and migrating to another profession (Amaravathi and Bhavana, 2019).

\section{Gender status}

Gender is a crucial variable in livelihood analysis. Usually male persons are mostly involved in weaving. Since, it is their traditional occupation, it is apprehended that all the family members are involved in the process. The gender status of the respondents was enlisted in fig. 2.

From the figure it is revealed that a vast majority $(98.69 \%)$ of respondents were male Bandha weavers and only $1.31 \%$ were female. Bandha weaving requires skill competency. Since, the respondents were comparatively resource poor and fully engaged in weaving for their livelihood, the 
male members had accumulated experience from their ancestors.

The findings are that the male members of the society were usually engaged in Bandha occupation and the females were supporting the male counterparts in the Bandha families to earn the livelihood support.

\section{Family type}

Each type of family has their respective advantages and disadvantages. Generally joint family is more progressive and relatively resource rich. The data collected on family type of the respondents was enlisted in table 2.

From the table it is revealed that majorities $(83.01 \%)$ of the respondents were having nuclear family system and only $16.99 \%$ of the respondents had joint family system.

The findings showed that majority of weavers had nuclear family system to avoid family burden and maintain their family individually.

\section{Education}

Education is most essential for an individual and also it brings desirable changes in knowledge, skill \& attitude. The educational distribution of the respondents was enlisted in table 3 .

From the table it is revealed that majority $(50.33 \%)$ of the respondents were educated up to primary level. Mixed responses were observed on educational status of the rest respondents. Even $9.15 \%$ of the respondents were illiterate.

The findings showed that the Bandha weavers were resource poor and involved in Bandha weaving irrespective of their educational status.

\section{Caste}

Our society is mostly caste based and basing their caste they have specific occupation and ritual status in a hierarchy. The caste distribution of the respondents was enlisted in table 4.

From the table it is revealed that majority (54.91\%) of Bandha weavers were belong to other backward caste followed by the same caste converting to Buddhist $42.48 \%$. There was no scheduled tribe and very few $1.96 \%$ belongs to schedule caste as well as general caste $0.65 \%$.

The findings showed that the respondents belong to weaver community particularly i.e. Gaudiapataras, Asanipataras, Saraka (Buddhist) and Rangani weavers i.e. Bandha weaving restricted to a particular caste group and having traditional occupation.

\section{Card holder category}

Govt. of India provided BPL card to weavers according to fulfill their basic needs and also provided Ration Card basing on their monthly income having less than Rs.10000/-. The data collected in this regard was enlisted in table 5.

From the table it is revealed that only $20.26 \%$ of the respondents were above poverty line. Out of the rest $80.00 \%$ of the respondents, $46.41 \%$ were ration card holders and $33.33 \%$ were below poverty line.

The findings are that majority of Bandha weavers were very poor and their monthly income is very less for which $79.74 \%$ of the respondents were ration card holders.

\section{Major occupation}

Occupation is very important for livelihood, indicating the status of a family and also income status of an individual. The principal 
occupational distribution of the respondents was enlisted in the table 6 .

From the table it is revealed that mixed responses were obtained where the respondents were involved in Bandha making, Bandha weaving and tasar reeling. However, most of the respondents had major occupation of Bandha making and weaving (42.48\%) followed by only Bandha making
$30.72 \%$ and only Bandha weaving $14.38 \%$. Negligible percentage of the respondents had Bandha making with weaving and tasar reeling $(8.50 \%)$, Bandha making with tasar reeling (3.27\%) and Bandha weaving with tasar reeling $(0.65 \%)$.

The findings concluded that majority of the respondents had Bandha making and weaving as the major occupation.

Table.1 Age distribution of the respondents $(\mathrm{n}=153)$

\begin{tabular}{|c|l|c|c|}
\hline Sl.No. & Age & Frequency & Percentage \\
\hline $\mathbf{1}$ & Young age (up to 35 yrs.) & 30 & 19.61 \\
\hline $\mathbf{2}$ & Middle age (35-50 yrs.) & 68 & 44.44 \\
\hline $\mathbf{3}$ & Upper age (above 50 yrs.) & 55 & 35.95 \\
\hline
\end{tabular}

Table.2 Family type distribution of the respondents $(n=153)$

\begin{tabular}{|c|l|c|c|}
\hline SI. No & Family type & Frequency & Percentage \\
\hline $\mathbf{1}$ & Nuclear family & 127 & 83.01 \\
\hline $\mathbf{2}$ & Joint family & 26 & 16.99 \\
\hline
\end{tabular}

Table.3 Educational status of the respondents $(\mathrm{n}=153)$

\begin{tabular}{|c|l|c|c|}
\hline SI.No. & Education & Frequency & Percentage \\
\hline $\mathbf{1}$ & Illiterate & 14 & 9.15 \\
\hline $\mathbf{2}$ & Literate & 5 & 3.27 \\
\hline $\mathbf{3}$ & Primary & 77 & 50.33 \\
\hline $\mathbf{4}$ & Upper primary & 28 & 18.30 \\
\hline $\mathbf{5}$ & High school & 22 & 14.38 \\
\hline $\mathbf{6}$ & College \& above & 7 & 4.57 \\
\hline
\end{tabular}

Table.4 Caste distribution of the respondents $(\mathrm{n}=153)$

\begin{tabular}{|c|l|c|c|}
\hline Sl.No. & Caste & Frequency & Percentage \\
\hline $\mathbf{1}$ & Scheduled Caste & 3 & 1.96 \\
\hline $\mathbf{2}$ & Other backward caste (OBC) & 84 & 54.91 \\
\hline $\mathbf{3}$ & Minority OBC(Buddhist) & 65 & 42.48 \\
\hline $\mathbf{4}$ & General & 1 & 0.65 \\
\hline
\end{tabular}


Table.5 Card holder category of the respondents $(\mathrm{n}=153)$

\begin{tabular}{|c|l|c|c|}
\hline Sl.no & Card holder & Frequency & Percentage \\
\hline $\mathbf{1}$ & BPL (Below Poverty Line) & 51 & 33.33 \\
\hline $\mathbf{2}$ & Ration card & 71 & 46.41 \\
\hline $\mathbf{3}$ & APL (Above poverty line) & 31 & 20.26 \\
\hline
\end{tabular}

Table.6 Major occupation of the respondents $(n=153)$

\begin{tabular}{|c|l|c|c|}
\hline Sl.no & Occupation & Frequency & Percentage \\
\hline $\mathbf{1}$ & Only Bandha making & 47 & 30.72 \\
\hline $\mathbf{2}$ & Only Bandha weaving & 22 & 14.38 \\
\hline $\mathbf{3}$ & Bandha making with Bandha weaving & 65 & 42.48 \\
\hline $\mathbf{4}$ & Bandha making with tasar reeling & 5 & 3.27 \\
\hline $\mathbf{5}$ & Bandha weaving with tasar reeling & 1 & 0.65 \\
\hline $\mathbf{6}$ & Bandha making with Bandha weaving with tasar reeling & 13 & 8.50 \\
\hline
\end{tabular}

Table.7 Subsidiary occupation of weaving households of respondents from other activities $(\mathrm{n}=$ 153)

\begin{tabular}{|c|l|c|c|}
\hline Sl.no & Subsidiary occupation & Frequency & Percentage \\
\hline $\mathbf{1 .}$ & Crop raising & 50 & 32.68 \\
\hline $\mathbf{2 .}$ & Dairy cow & 21 & 13.73 \\
\hline $\mathbf{3 .}$ & Petty business & 6 & 3.92 \\
\hline $\mathbf{4 .}$ & Service holder & 15 & 9.80 \\
\hline $\mathbf{5 .}$ & Priest weaver & 1 & 0.65 \\
\hline $\mathbf{6 .}$ & Labourer & 10 & 6.54 \\
\hline $\mathbf{7 .}$ & No subsidiary occupation & 50 & 32.68 \\
\hline
\end{tabular}

Table.8 Work experience of the respondents $(n=153)$

\begin{tabular}{|r|l|c|c|}
\hline Sl.no & Work experience & Frequency & Percentage \\
\hline $\mathbf{1}$ & Up to 10 yrs. & 16 & 10.46 \\
\hline $\mathbf{2}$ & $11-20$ yrs. & 34 & 22.22 \\
\hline $\mathbf{3}$ & 21-30yrs & 55 & 35.95 \\
\hline $\mathbf{4}$ & 31-40yrs & 36 & 23.53 \\
\hline $\mathbf{5}$ & Above $41 \mathrm{yrs}$ & 12 & 7.84 \\
\hline
\end{tabular}

Table.9 Sources of learning on weaving of the respondents $(n=153)$

\begin{tabular}{|c|l|c|c|}
\hline Sl.No & Learning sources & Frequency & Percentage \\
\hline $\mathbf{1}$ & Only Parents & 88 & 57.52 \\
\hline $\mathbf{2}$ & Only Master Weavers & 30 & 19.61 \\
\hline $\mathbf{3}$ & Parents with Master Weavers & 34 & 22.22 \\
\hline $\mathbf{4}$ & Parents with weavers co-operative Society & 1 & 0.65 \\
\hline
\end{tabular}


Table.10 Extent of hours per day spent on weaving $(n=153)$

\begin{tabular}{|c|l|c|c|}
\hline Sl.No. & $\begin{array}{l}\text { Working hours per } \\
\text { day }\end{array}$ & Frequency & Percentage \\
\hline $\mathbf{1}$ & $2-4 \mathrm{hrs}$ & 2 & 1.31 \\
\hline $\mathbf{2}$ & $4-8 \mathrm{hrs}$ & 119 & 77.78 \\
\hline $\mathbf{3}$ & $8-12 \mathrm{hrs}$ & 32 & 20.91 \\
\hline
\end{tabular}

Table.11 Accommodation facilities available $(\mathrm{n}=153)$

\begin{tabular}{|c|l|c|c|}
\hline Sl.no & Accommodation facility & Frequency & Percentage \\
\hline $\mathbf{1}$ & Inherited house & 133 & 86.93 \\
\hline $\mathbf{2}$ & Self-acquired house & 18 & 11.76 \\
\hline $\mathbf{3}$ & Rented house & 2 & 1.31 \\
\hline
\end{tabular}

Table.12 Possession of tools and equipments by the respondents $(n=153)$

\begin{tabular}{|r|l|c|c|}
\hline Sl.no & Tools and equipments & Frequency & Percentage \\
\hline $\mathbf{1}$ & Only Pit loom & 10 & 6.54 \\
\hline $\mathbf{2}$ & Frame loom with pit loom & 12 & 7.84 \\
\hline $\mathbf{3}$ & Only Bandha frames & 44 & 28.76 \\
\hline $\mathbf{4}$ & Bandha frame with pit loom & 46 & 30.06 \\
\hline $\mathbf{5}$ & Bandha frame with frame loom & 16 & 10.46 \\
\hline $\mathbf{6}$ & Bandha frame with pit loom with drum & 11 & 7.19 \\
\hline $\mathbf{7}$ & Bandha frame with frame loom with dobby & 13 & 8.5 \\
\hline $\mathbf{8}$ & Only jacquard & 1 & 0.65 \\
\hline
\end{tabular}

Table.13 Work category of the respondents $(n=153)$

\begin{tabular}{|c|l|c|c|}
\hline Sl.No & Work category & Frequency & Percentage \\
\hline $\mathbf{1}$ & Only EW & 18 & 11.76 \\
\hline $\mathbf{2}$ & Only WCS & 2 & 1.31 \\
\hline $\mathbf{3}$ & Only MW & 22 & 14.38 \\
\hline $\mathbf{4}$ & WCS with MW & 19 & 33.99 \\
\hline $\mathbf{5}$ & EW with WCS & 2 & 12.41 \\
\hline $\mathbf{6}$ & EW with MW & 2 & 1.31 \\
\hline $\mathbf{7}$ & EW with WT & 33 & 1.31 \\
\hline $\mathbf{8}$ & EW with WCS with MW & 2 & 21.57 \\
\hline $\mathbf{9}$ & EW with WCS with WT & 1 & 1.31 \\
\hline $\mathbf{1 0}$ & WCS with MW with WT & 1 & 0.65 \\
\hline
\end{tabular}

Note: EW: Entrepreneur Weaver, WCS: Weavers Co-operative society, MW: Master Weaver, WT: Working under Trader 
Table.14 Membership status of the respondents $(n=153)$

\begin{tabular}{|c|l|c|c|}
\hline Sl.No & Membership status & Frequency & Percentage \\
\hline $\mathbf{1}$ & Only WCS member & 74 & 48.37 \\
\hline $\mathbf{2}$ & Only SHG member & 14 & 9.15 \\
\hline $\mathbf{3}$ & Both WCS with SHG & 37 & 24.18 \\
\hline $\mathbf{4}$ & No member & 28 & 18.3 \\
\hline
\end{tabular}

Note: WCS: Weavers Co-operative society, SHG: Self-Help Group

Map of India highlighting state of OdishaMap of Odisha highlighting the Cuttack district

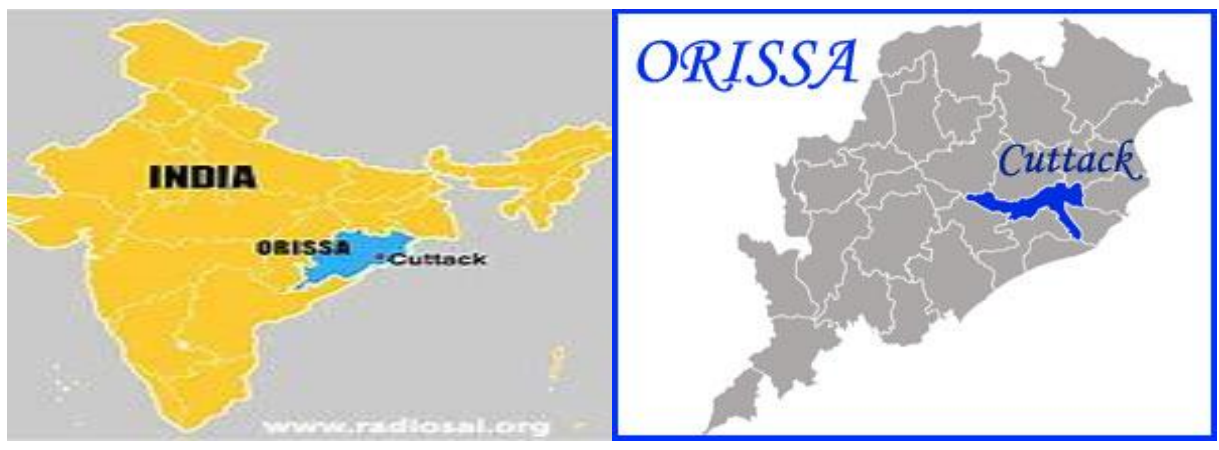

Fig.1 Location of study area (Tigiria, Badamba, Banki dampara blocks of Cuttack district of Odisha, India)

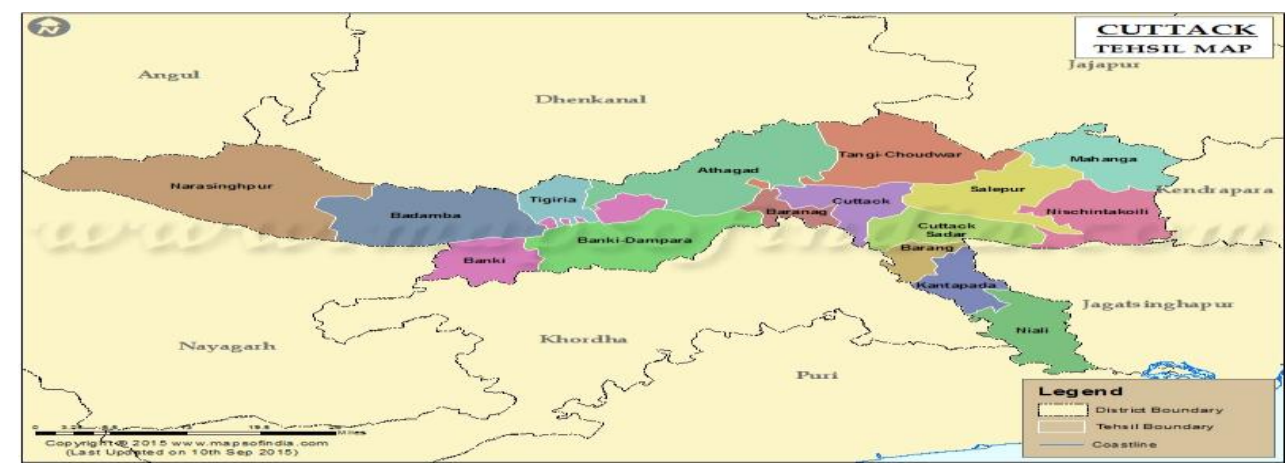

Fig.2 Gender status of the respondents $(\mathrm{n}=153)$

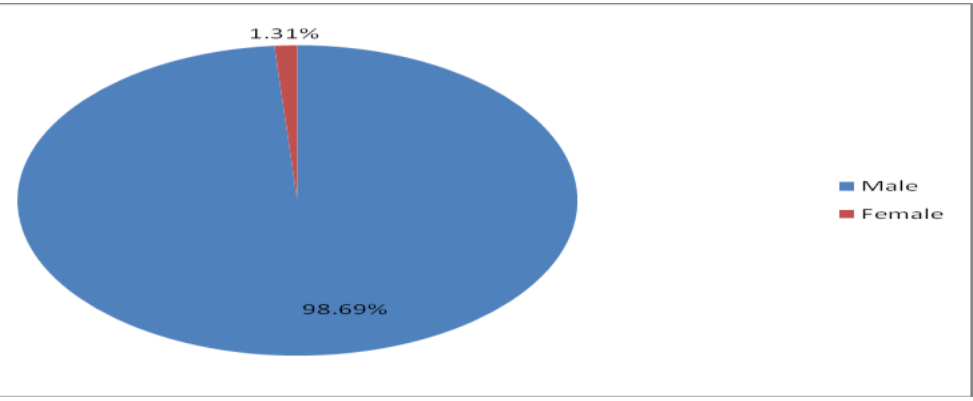


Fig.3 Income generated on handloom products per month by respondents $(n-=153)$

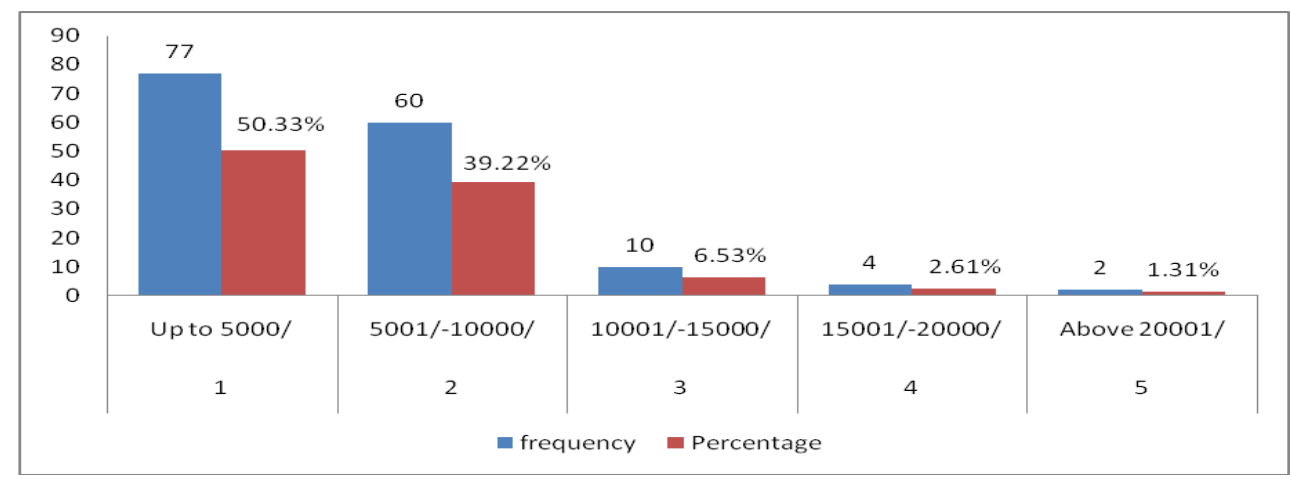

\section{Subsidiary occupation}

Attempt was also made to analyse the subsidiary occupation of the sample respondents. The result obtained was enlisted in table 7.

From the table it is revealed that $32.68 \%$ of the respondent households had no subsidiary occupation. Only $32.68 \%$ of the respondent households had crop production as the subsidiary occupation followed by $13.73 \%$ keeping dairy cows, $3.92 \%$ petty business, $9.80 \%$ service holders and negligible percentage having priest weaving $(0.65 \%)$ as well as working as labourer (6.54\%).

The findings are that the respondents had not much of subsidiary occupation and mostly involved in weaving for their livelihood.

\section{Work experience}

Bandha weaving is the traditional and principal occupation of the respondents as observed from the earlier findings. Therefore, attempt was made to analyse their experience in these occupations and the data was enlisted in table 8 .

From the table it is revealed that mixed responses were obtained on the work experience on Bandha weaving. Majority $(35.95 \%)$ of the respondents had experience of 21-30 years followed by 31-40 years (23.53\%), 11-20 years $(22.22 \%)$, up to 10 years $(10.46 \%)$ and only $7.84 \%$ having experience of above 41 years.

The findings showed that majority $(59.48 \%)$ of the respondents had rich experience and engaged in Bandha weaving since last 21 to 40 years. Older peoples are usually not much involved in the profession due to age factor.

\section{Source of learning}

The state as well as Central Government has launched different schemes to develop the knowledge and skill competency of the Bandha weaves. They are also being trained in private sectors particularly by master weavers and from their ancestors. Attempt was therefore made in the study to assess the source of learning of the respondents. The data obtained was enlisted in table 9.

From the table it is revealed that majority $(57.52 \%)$ of the respondents learned the weaving from their parents/ancestors. Similarly, 22.22\% learned from their parents along with master weavers and $19.61 \%$ from the master weavers only. Weaver's cooperative society had not extended much technical support to the weavers on weaving.

The findings showed that Bandha weaving is their traditional occupation of the respondents 
and techniques of Bandha weaving usually transfer generation after generation (Pangging, 2020).

\section{Working hours per day}

Since, Bandha weaving is the principal occupation of the respondents, it is expected that they are working sufficient hours per day on Bandha weaving. The data collected on working hours per day of the respondents was enlisted in the table 10 .

From the table it is revealed that majority $(77.78 \%)$ of the respondents spent $4-8$ hours per day on weaving. $20.91 \%$ of the respondents were spending even 8-12 hours per day in weaving and $1.31 \%$ were spending 2-4hrs/day.

The findings concluded that Bandha weaving is the major source of income for their livelihood and suggested for adequate support either from Govt., public or private sector for their livelihood.

\section{Accommodation facility}

Type of residential house indicates the status of an individual in the society. The families having better income usually reside in a better house. Convenient work space, proper lightening and ventilation are also another consideration for Bandha weaving skillfully. The data collected from the respondents on accommodation facilities was enlisted in table 11.

The data from the table revealed that majority $(86.93 \%)$ of Bandha weavers were living in their parental houses. Only $11.76 \%$ weavers had constructed their own house and rest $1.31 \%$ weavers live in rented house.

The findings concluded that the economic status of the respondents have not much improved for which they are still residing in their old houses may with minor repairing and maintenance. They definitely deserve some outside support for their livelihood.

\section{Possession of tools and equipments}

Possession of implements and machineries indicates the progressiveness of weaver's families and involvement in scientific weaving. It also one of the indicator for the profitability in weaving. The data collected on possession of tools and equipments by the respondents for weaving was enlisted in table 12.

From the table it is revealed that majority of the respondents had possessed Bandha frame with pit loom (30.06\%) followed by only Bandha frames $(28.76 \%)$. Very few of the respondents had Bandha frame with frame loom (10.46\%), Bandha frame with frame loom with dobby ( $8.5 \%)$, frame loom with pit loom (7.84\%), Bandha frame with pit loom with drum (7.19\%) and only pit loom $(6.54 \%)$. Negligible percentage of jacquard $(0.65 \%)$.

The findings showed that weavers mostly used Bandha frames since it is their major occupation and pit looms because of its more stability and strength as compared to frame loom. Few respondents had drum, dobby and very negligible jacquard machine because of lack of finance as it is very costly. They were doing their work in rent basis. It is therefore suggested that the Government should intervene and extend possible support in providing tools and machineries to the respondents for better work efficiency and income generation for their improvement.

\section{Work category}

Since, Bandha weavers were very poor, they depend upon multiple work categories for 
their livelihood. The data collected on work category of the respondents was enlisted in table 13 .

From the table it is revealed that mixed responses were observed from the respondents. Not a single respondent was found to be the only traders, membership in handloom development Corporation, Boyanika or Serifed. Very few percentage $(1.31 \%)$ of the respondents were exclusively under weavers Co-operative society, entrepreneur weaver with working under trader or master weaver as well as entrepreneur weaver along with working under weaver cooperative society and traders. Only $0.65 \%$ of the respondents were under the work category of weaver's cooperative society along with master weaver and trader. The critical analysis of the data in the table indicated that most of the respondents were in the work category of weaver cooperative society with master weavers $(33.99 \%)$ followed by entrepreneur weaver with weaver cooperative society and master weavers (21.57\%), only master weavers (14.38\%), entrepreneur weavers with weaver cooperative society $(12.41 \%)$ and only entrepreneur weavers $(11.76 \%)$.

The findings revealed that the respondents were mainly working under weaver's cooperative society and master weavers as a wage worker since they were very poor and cannot establish their own entrepreneur due to lack of finance.

\section{Membership position}

Weavers co-operative society has been established to provide support to the weavers for their traditional occupation of weaving. Self Help Group concept is also organized at Govt., private and public section for the improvement of the Bandha weavers. The Attempt was therefore made in the study to access the membership status of the Bandha weavers. The data collected from the respondents on their membership status was enlisted in table 14.

From the figure it is revealed that though mixed responses were observed on the membership status of respondents. $48.37 \%$ were only the member of weaver co-operative society, $24.18 \%$ members of both the weaver's cooperative society and Self Help Groups. 9.15\% were the members of Self Help Groups only and $18.30 \%$ not any members.

Findings lead to conclude that majority of the respondents were the members of the weavers cooperative society to get the Govt. benefits such as $11.76 \%$ weavers get loom accessories, $51.63 \%$ get solar lanteen, $28.75 \%$ get MBBY insurance, $1.96 \%$ get cementing of pit, $11.11 \%$ get work shed and $1.30 \%$ get loom.

\section{Income generation}

Financial soundness is the indicator of empowerment and adoption of improved technologies. Financial status helps the weaver for progressive thinking and search for better technologies to increase income further. Attempt was therefore made in the study to assess the approximate income generated by the weavers per month. The data collected from the respondents was enlisted in fig. 3 .

From the figure it is revealed that income generated by the respondents through weaving was not encouraging. Majority $(50.33 \%)$ of the respondents were generating meagre income of within Rs.5000/- per month (Fourth All India Handloom Census, Govt. of India, 2019; Rath and Panda, 2017; Panda and Parida, 2019; Raju and Rao, 2014). 39.22\% respondents generating monthly income of Rs.5001/ to Rs.10000/. Very few respondents 
were generating monthly income of Rs.10001/ to Rs.15000/ (6.53\%), Rs.15001/ to Rs.20000/ (2.61\%) and above Rs.20001/ $(1.31 \%)$.

The findings showed that the respondents were resulting low income which is definitely a burden to maintain their livelihood. They were relatively resource poor and might have opting for their traditional occupation of weaving on compulsion.

In conclusions the present study focuses on the socio-economic status of the indigenous Bandha weavers of Cuttack district of Odisha. Usually they are resource poor and fully depend on their traditional occupation of Bandha weaving for livelihood. They are not using any advanced tools, equipments and techniques for weaving and major source of learning was from their ancestors. Mainly they are working under weaver's cooperative society and master weavers as a wage worker. Increased unfair competition from the power loom affect their livelihood. Majority of weavers are monthly income within Rs.5000/having no other subsidiary income. Younger generations are not much involved in weaving and migrating to other professions. It is therefore suggested to Govt. to take initiatives such as convenient infrastructural facilities, ensuring easy availability of better machineries with repair and maintenance facilities, subsidy facilities may be provided as incentives in procuring having machineries and tools for better work efficiency and income generation, regular training along with exposure visit to develop knowledge and skill competency on advanced technology, regular guidance by the expert trainers, skill competency on improved dyeing and designing, creating marketing avenues and regular participation in exhibitions and fairs, introduction of special scheme for Bandha weavers, strengthening of the cooperative sectors, planning for feasible income generating activities for the family members for substantial income, increased conversion charges(wages) since it is laborious and a traditional art of Odisha etc. to increase their economic conditions and livelihood system. The study therefore conclude that the state Government developmental department as well as district administration have to analyse all these suggestive measures and extend all feasible supports for the improvement of the Bandha weavers and sustainability of the said Bandha products.

\section{References}

Amaravathi, G. and Bhavana Raj, K.2019.Indian Handloom Sector - A Glimpse, International Journal of Innovative Technology and Exploring Engineering, 8(6S4): 645-654.

Anand, G. 2017. Livelihood sustainability of handloom weavers, Bachelors degree of Arts in social sciences, Tata Institute of Social Sciences, Guwahati.

Annual report. 2018. Ministry of Textiles, Government of India, New Delhi.

Banerjee, A. N., Pandit, P. and Roy Maulik, S. 2019. Eco-friendly approaches to rejuvenate the Khadi udyog in Assam, Indian Journal of Traditional Knowledge, 18 (2): 346-350.

Behera, S., Khandual, A. and Luximon, Y. 2019. An Insight In To the Ikat Technology in India: Ancient To Modern Era, IOSR Journal of Polymer and Textile Engineering (IOSR-JPTE), 6 (1): 28-51.

Das Ghosh,K. and Jena,S.K. 2018.Indigenous Knowledge, Inclusive Innovation And Entrepreneurial Success of Sambalpuri Handlooms: An Analysis, International Journal for Research in Engineering Application \& Management, 4(3): 230-242.

Das, P. 1994. Bandha fabrics of Orissa: an aesthetic textile tradition selected case studies, Ph.D. Thesis, Utkal University, Vanivihar, Bhubaneswar, Orissa.

Das, S. R. 2015. Socio-Economic Profile of Handloom Weaving Community: A Case Study of Bargarh District, Odisha, Master's degree of Arts in Development Studies, 
Department of Humanities and Social Sciences, National Institute of Technology, Rourkela, Odisha, India.

Fourth All India Handloom Census. 2019. Office of the Development Commissioner for Handlooms, Govt. of India, Ministry of Textiles, New Delhi.

Lakshmy Devi, C.S. 2014. An analysis of socioeconomic status of handloom workers in India, International Journal of Business and Administration Research Review, 3 (5): 622.

Maulik, S. R. and Agarwal, K. 2014. Painting on handloom cotton fabric with colourants extracted from natural sources, Indian Journal of Traditional Knowledge, 13 (3): 589-595.

Mishra, K. 2018. Socio Economic Growth of Handloom: An Empirical Study, IOSR Journal of Business and Management, 20 (3): 21-34.

Mohapatra, N. A. 2014. Management Approach to Sambalpuri Sari with a Sign of Cultural Facets, Odisha Review, 30-135.

Outcome budget. 2015. Ministry of Textiles, Government of India, New Delhi.

Outcome budget. 2017. Department of Handloom, Textile and Handicrafts, Odisha.

Panda, S., and Parida, C.2019. A Case for Conservation of the Sustainable Vernacular Weavers' Settlement at Nuapatna, Odisha, International Journal of Applied Engineering Research, 14(6): 1420-1425.

Pangging, G., Sharma, C. L., Sharma, M., Rai, N. and Gogoi, J. 2020. Traditional handloom practices of Nyishi tribe of Arunachal Pradesh, Eastern Himalaya, Indian Journal of Traditional Knowledge, 19 (2): 442-449.

Patra, S. K. 2015. Lord's Fabric, Weavers' Service Centre, Bhubaneswar, Odisha
Review, Pp. 166-170.

Prayas. 2015. Ministry of Textiles, Government of India, New Delhi.

Raju, G.N., and Rao, K.V. 2014. A Study on the Socio-economic conditions of Handloom weavers, Journal of Rural Development, 33 (3): 309-328.

Raju, K.D., and Chaudhary, S. 2013. Geographical Indications in Odisha: A Leading Destination of Traditional Handlooms, Odisha Review, 38-44.

Rath, N. and Panda, S. 2017. Traditional Handwoven Khandua of Nuapatna and Maniabandha -A Navigation into its Ancestry and Analyzing the Present, IJARIIE, 3(4): 2741-2752.

Report of Textile Committe. 2008. Khandua Sarees and Fabrics- Tradition and Pride of Orissa, Ministry of Textiles, Govt. of India, New Delhi.

Roy, A. N. and Basu, G. 2010. Improvement of a traditional knowledge by development of jacquard shedding based handloom for weaving ornamental jute fabric, Indian Journal of Traditional Knowledge, 9(3): 585-590.

Sudhakar, P. and Padmavathi, A. 2019. Socioeconomic conditions of handloom weavers in Kadapa and Chittoor districts of Andhra Pradesh, Indian Journal of Research, 8(5):13-15.

Tripathy, G. S. 2009. Odisha Handlooms: Problems and Perspectives, Odisha review, 54-56.

Vijaya Lakshmi, V.,Deepika, J. and Gayathri Devi, M. 2019. Assessment of SocioEconomic Status of Pochampally Ikat Handloom Weavers, Int.J. Curr. Microbiol. App. Sci., 8(10): 573-579.

\section{How to cite this article:}

Shubhasri Sahoo. 2020. Assessment of Socio-economic Profiles for the Livelihood Generation of Bandha Weavers of Cuttack District of Odisha. Int.J.Curr.Microbiol.App.Sci. 9(12): 28932906. doi: https://doi.org/10.20546/ijcmas.2020.912.344 